THE LEGITIMIZATION STRATEGY OF THE TALIBAN'S CODE OF CONDUCT 



\title{
The Legitimization Strategy of the Taliban's Code of Conduct
}

\section{Through the One-Way Mirror}

\author{
Yoshinobu Nagamine
}




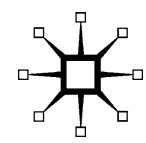

THE LEGITIMIZATION STRATEGY OF THE TALIBAN'S CODE OF CONDUCT

Copyright (C) Yoshinobu Nagamine, 2015.

Softcover reprint of the hardcover 1st edition 2015 978-1-137-53716-4

All rights reserved.

First published in 2015 by

PALGRAVE MACMILLAN ${ }^{\circledR}$

in the United States-a division of St. Martin's Press LLC,

175 Fifth Avenue, New York, NY 10010.

Where this book is distributed in the UK, Europe and the rest of the world, this is by Palgrave Macmillan, a division of Macmillan Publishers Limited, registered in England, company number 785998, of Houndmills, Basingstoke, Hampshire RG21 6XS.

Palgrave Macmillan is the global academic imprint of the above companies and has companies and representatives throughout the world.

Palgrave ${ }^{\circledR}$ and Macmillan ${ }^{\circledR}$ are registered trademarks in the United States, the United Kingdom, Europe and other countries.

ISBN 978-1-349-57626-5

ISBN 978-1-137-53088-2 (eBook)

DOI 10.1007/978-1-137-53088-2

Library of Congress Cataloging-in-Publication Data

Nagamine, Yoshinobu, author.

The legitimization strategy of the Taliban's code of conduct : through the one-way mirror / Yoshinobu Nagamine.

pages $\mathrm{cm}$

Includes bibliographical references and index.

1. Afghan War, 2001-Law and legislation. 2. Taliban. 3. War (Islamic law)Afghanistan. 4. Humanitarian law. I. Title.

KZ6795.T47N34 2015

343.581'014-dc23

2015013124

A catalogue record of the book is available from the British Library.

Design by Newgen Knowledge Works (P) Ltd., Chennai, India.

First edition: October 2015

10987654321 
For the people of Afghanistan. 



\section{Contents}

List of Illustrations $\quad$ ix

Preface $\quad$ xi

Acknowledgments $\quad \mathrm{xV}$

List of Abbreviations xvii

Glossary $\quad$ xix

Chapter 1

Introduction 1

Chapter 2

Background to Afghanistan and the Taliban 11

Chapter 3

Layeha-the Code of Conduct of the Taliban 27

Chapter 4

Comparison with Pashtunwali 45

Chapter 5

Comparison with Islamic Law 53

Chapter 6

Comparison with International Humanitarian Law 73

Chapter 7

Application and Perception of the Layeha by the Taliban 91

Chapter 8

Conclusion: Layeha, a One-Way Mirror? 103

Annex I: Interview with Top Taliban Leaders (NHK) 125

Annex II: New Directive from Amir ul-Momineen Mullah
Mohammad Omar Mujahid (September 14, 2009)

Annex III: Taliban's Code of Conduct $\quad 145$ 
viii CONTENTS

Annex IV: Sample Questionnaire for the Taliban on the Layeha 163 Annex V: Interviews with Taliban Members on the Layeha

Notes

Bibliography

Index 


\section{Illustrations}

\section{Figures}

3.1 Hypothetical flow of the legitimization process 30

7.1 Flowchart of sanctions in case of violation of the Layeha 99

8.1 Normative allusion of the Layeha to various norms 104

8.2 Normative convergence of the Layeha with various norms 105

8.3 Normative perception of the Layeha by Taliban members 109

8.4 Analogy of the "one-way mirror" 111

\section{Tables}

2.1 Casualty figures caused by suicide bombing 21

2.2 Casualty figures caused by IEDs 21

3.1 Date of publication and mention in the media 33

3.2 Content of the 2006 Layeha 34

3.3 Content of the 2009 and 2010 Layeha 35

3.4 Thematic overview of the 2009 Layeha compared

3.5 Thematic overview of the 2010 Layeha compared with the 2009 Layeha 40

4.1 Comparison between Pashtunwali and the Layeha 51

5.1 Different variations of Jihad doctrines 56

5.2 Categories of people enjoying protection under Islamic law 62

5.3 Comparison between Islamic law and the Layeha 70

6.1 Targetability as defined in the 2006 Layeha 79

6.2 Targetability as defined in the 2009 and 2010 Layeha 79

6.3 Comparison between IHL and the Layeha 89

8.1 Different approaches to ANSA analyzed under
the "one-way mirror model" 



\section{Preface}

$\mathrm{T}_{\mathrm{h}}$ he cascade of events inevitably forces practitioners to keep abreast with the latest developments at the cost of not reflecting enough on past lessons. As a humanitarian worker, I myself belonged to this specie of practitioners focusing from one crisis to the other. The work in Afghanistan brought me to the heart of insurgency, which challenged me with questions about the origin and the motives of the Taliban. What lessons can be drawn from the current dealing with the Taliban and what are the leverages to influence the Taliban? I then came across the Layeha, the Code of Conduct issued by the Taliban, and wondered what impact such a Code exerted on the actual conduct of hostilities. The idea captivated me that the analysis of the Taliban's value system based on the Code of Conduct might lead to a serendipitous insight as to how to influence the Taliban in favor of protection of civilians.

The thrust of the research is the following. The sudden ascent of the Taliban to power in the early 1990s is often ascribed to the military strategy and the material assistance from neighboring countries but less to the popular acclaim the Taliban enjoyed at the outset. It is the latter that the research intends to dwell on. The research first argues that the Taliban could not have thrived without the particular circumstance in which the movement found fertile soil. It considers the Taliban as "an indigenous, situational and reactional phenomenon" of the Afghan society as adequately coined by a professor of Peshawar University and less as an external entity concocted in the radicalized madrassas of the refugee camps in Pakistan. A Taliban spokesman once likened Afghanistan to a mirror image of the world: "If you do not like your image in the mirror, don't break the mirror but break your face." Similarly, the Afghan society is reflected in the Taliban movement, which cannot be dissociated from the former.

The decade-long Soviet occupation and the armed resistance left a destructive impact on life and property of the population just to be followed by another devastating period of internecine fighting among warlords. Accordingly, the understanding as to what constitutes an ideal leader also changed with the course of events. After a long period of hereditary successions of royal authority, political legitimacy came to be bestowed on those who vowed to defend religious values and resist Soviet occupation. After the Soviet withdrawal, anybody who managed to disarm the marauding warlords 
and to ensure security was hailed as a redeemer. Not surprisingly, the manifesto of the Taliban to restore law and order based on a strict interpretation of Sharia law resonated with many Afghans. The "peace in the graveyard" under the Taliban regime was still to be preferred to the previous period of chaos and lawlessness.

After the ousting of the Taliban from Afghanistan in 2001, the introduction of presidential democracy based on popular vote and recognition of Afghanistan as a full-fledged member of the international community represented a challenge to the previous way how legitimacy was defined and acquired. The Taliban pilloried the weakness of the Karzai government and started an insurgency against the coalition forces. They evoked Jihad and let revive the old label of Mujahideen (freedom fighter) with the hope of gaining the same level of legitimacy the members used to be bestowed. The difference today, however, is that armed struggle no longer coincides with what is considered legitimate by the so-called community of liberal states. Today, recognition is granted to those who effectively protects their own population from physical threat, provide social service, and elevates their general standard of living.

Against this backdrop, the Taliban is obdurately sandwiched between the old way of acquiring legitimacy through armed struggle and the new reality of legitimacy associated with responsible government. In the course of interaction with its own fighters and international community, the Taliban is undergoing an identity split; to its own members, the Taliban articulates the old rhetoric of Jihad against the invading non-believers, whereas to the external community it alludes to complying with international and humanitarian norms. Nothing exemplifies better than the Taliban's Code of Conduct, which I attempt to illustrate with a model termed the "one-way mirror." It is open to interpretation whether the Taliban's response is an outcome of bedeviled soul-searching or of a cool-minded calculated strategy. What can be at least inferred is that the double-pronged rhetoric is used consistently throughout Afghanistan and that this insight leads to new hints and reflection on how to deal with the current insurgency in Afghanistan.

More than a decade has passed since the Taliban insurgency in Afghanistan made its appearance and since the Coalition Forces became entangled in a long and protracted war. Now, the international forces begin to withdraw from Afghanistan and the world attention is on the armed conflicts in Syria and Iraq. Again, Afghanistan is on the verge of falling into oblivion reminiscent of the times when the Soviet forces withdrew and when the world was transfixed by the wars in Yugoslavia, Rwanda, and Somalia. On the other hand, the withdrawal from Afghanistan may also represent an opportunity, as the international community has become more susceptible to alternative solutions other than kinetic ones. In search for a less costly and sustainable solution in Afghanistan, a thorough reality check and analysis of the political dynamics, the insurgency, and the coalition's response are primordial-and this book hopes to make a modest contribution in this regard. 
The reader may forgive me for the academic tone of the book as it was conducted in the framework of $\mathrm{PhD}$ dissertation at the University of Tokyo. In order to make the book readable to a wide audience, utmost care was paid to omit academic jargon and keep theory to the minimum. The opinions stated in the following research are those of the researcher alone and do not reflect the views of any of his organizations. All interviews used herein were conducted in the private capacity of the author.

Last but not least, I cannot hide my surreptitious wish that this book is read, commented, and reflected upon by the Taliban members themselves. After all, a sustainable solution in Afghanistan can only be found with the inclusion of all stakeholders, including, whether we like it or not, the Afghan Taliban. 



\section{Acknowledgments}

I am highly indebted to a considerable number of persons without whose help the current research could not have been conducted. I would first like to thank researchers and practitioners based or living in Afghanistan, in particular Abdul Rahman, Danish, Farida, Fazel, Gulmar, Heather, Ishaq, Karimi, Kate, Muzafary, Nader, Noorzai, Rafiq, Roohafza, Sabrina, Sarah, Subel, Shinichi, Takuro, Thomas, Waheed, and Zubair, the full names of whom I prefer not to mention. Persons based in Pakistan were also helpful in the research, such as Abdul Rauf, Babr, Imdad, Imtiaz, Maulana, Nasreen, Rana, Sarfraz, Salma, Sami, Sayed, Syed, and Zia.

I also would like to thank the various experts who helped me to develop and contextualize my research, in particular Alexander Neill, Antonio Giustozzi, Ahmed Rashid, Michel Semple, Jonathan Goodhand, Christopher Langton, and Thomas Ruttig. As for resource persons in Japan, I appreciate the assistance of Akira Naito, Masato Toriya, Miyata Osamu, Rashid Khaled, So Yamane, and the Afghan students Farasoo and Ahmadzai. Special thanks go to Asahi, BBC, Deutsche Welle, Kyodo, NHK, and Pajhwok media bureau for their cooperation. As for logistics and technical support, I would like to thank Frank, Jason, Marco, Mashhood, Roohafza, Shah Jehan, and Yoshimi. The research trips would not have been possible without the generous funding from the Research Institute of Peace and Security and the Global Studies Programme of Tokyo University. The International Peace Cooperation Bureau of the Cabinet Office also generously offered its infrastructure during my last year of research.

I would like to thank, in particular, Professors Yasunobu Sato, Akira Kotera, Atsushi Okuda, Jun Ishida, Mitsugi Endo, Yoshinobu Yamamoto, and Yumi Nishimura for their invaluable guidance. I am greatly indebted to Professor Muhammad Munir from the International Islamic University of Islamabad who kindly guided me through the complexity of Islamic law, and to Keiichiro Okimoto who kindly reviewed the chapter on humanitarian law. Discussions with colleagues of the Cabinet Office were helpful in refining the research. I would like to express my appreciation for comments and encouragements from Masahara Nishihara and the ambassadors Misako Kaji, Hideki Asahi, (Judge) Hisashi Owada, and Reiichiro Takahashi, as well as for the moral support from Dylan Scudder, Hisashi Tsuya, K. from 
Kandahar, Ryo Maeda, Tomoaki Murakami and Sachiyo Yoshida. Special thanks go to my parents, for whom I cannot find words grand enough to show my appreciation for their confidence and love during all these years.

Finally, I cannot hide my shock and deep regret at learning of the passing away of Professor Akira Kotera and feel greatly honored to have received his final guidance. His persistent encouragement to think critically will be fondly remembered. 


\section{Abbreviations}

AAN Afghanistan Analysts Network

AGE anti-government element

AIP Afghan Independent Press

ALP Afghan Local Police

ANA Afghan National Army

ANP Afghan National Police

ANSA armed non-state actor

ANSO Afghanistan Non-governmental Security Office

API 1977 First Additional Protocol to the 1949 Geneva Conventions

APII 1977 Second Additional Protocol to the 1949 Geneva Conventions

APRP AfghanistanP eacea ndR eintegrationP rogram

ATT Afghan Transit Trade

BKTEF Baacha Khan Trust Educational Foundation

CMC Conflict Monitor Center

CPOST Chicago Project on Security and Terrorism

DCAF Geneva Centre for the Democratic Control of Armed Forces

$\mathrm{DPH} \quad$ Direct Participation in Hostilities

GC 1949 Four Geneva Conventions

HRW Human Rights Watch

ICC International Criminal Court

ICJ International Court of Justice

ICRC International Committee of the Red Cross

ICTY International Criminal Tribunal for the former Yugoslavia

IEA Islamic Emirate of Afghanistan (Taliban's own appellation for Islamic Republic of Afghanistan)

IED improvised explosive device

IHL International Humanitarian Law

IHR International Human Rights Law

IIHL International Institute of Humanitarian Law

INGO international non-governmental organization

IRA IrishR epublicanA rmy

IRIN Integrated Regional Information Networks

ISAF International Security Assistance Force 
ISI Inter-Services Intelligence of Pakistan

JETRO Japan External Trade Organization

JICA Japan International Cooperation Agency

KLA Kosovo Liberation Army

KP Khyber Pakhtunkhwa (Province of Pakistan)

LTTE Liberation Tigers of Tamil Ealam

NGO non-governmental organization

NHK Nippon Hoso Kyokai (Japan Broadcasting Corporation)

NSA non-state actor

NSAG non-state armed group (same as ANSA)

NWFP North-West Frontier Province of Pakistan, since 2010 Khyber Pakhtunkhwa

OCHA UN Office for the Coordination of Humanitarian Affairs

POW prisoner of war

PRT ProvincialR econstructionT eam

PTS Program for Strengthening Peace (in Dari)

RUSI Royal United Services Institute

TTP Tehrik-i-Taliban Pakistan (Pakistani Taliban)

UAE United Arab Emirates

UNAMA UN Assistance Mission to Afghanistan

UNDSS UN Department of Safety and Security

UNHCHR UN High Commissioner for Human Rights

UNODC UN Office on Drugs and Crime

USAID US Agency for International Development

USIP US Institute of Peace 


\title{
Glossary
}

\author{
al Samood \\ name of Taliban's Arabic language magazine \\ alim \\ Islamic scholar (Arabic, Dari, Pashto) \\ amir \\ leader, king (Arabic) \\ amir ul-Momineen \\ Commander of the Faithful (Arabic) \\ amr bi-l-ma'rufwa \\ nabw al-munkir \\ General Department for the Preservation of Virtue \\ and the Elimination of Vice (Arabic)

andival
ansar
aql
asaasi qanoon
asif
bacha bazi
badal
baghy
beit ul-mal
da amalyaato
porosa
dar al-islam
dar al-harb
darūra
dawah
Deobandi \\ din \\ Durrani \\ ezat \\ fard \\ fedayeen \\ comradesi na rms( Pashto) \\ helpers, alluding to those who accommodated the \\ refugees from Makka to Medina during the time of \\ the Prophet (Arabic) \\ intellect (Arabic, Pashto) \\ constitution (Dari) \\ servant (Arabic) \\ literally boy play, where boys are prostituted in an auc- \\ tion to the highest bidder (Dari) \\ revenge (Pashto, Dari) \\ (doctrine of) rebellion (Arabic) \\ public property under Islamic law (Arabic) \\ procedure of operations (Pashto) \\ abodeo fpe ace( Arabic) \\ abode of war (Arabic) \\ principle of necessity (Arabic) \\ invitation (Arabic) \\ Islamic revivalist movement based on strict adherence \\ to Qur'an and Sunnah \\ religion (Arabic) \\ Pashtun tribal confederation in southern and south- \\ eastern Afghanistan and western Pakistan \\ honor (Pashto) \\ religious obligation (Arabic, Dari, Pashto) \\ redeemers, "those who sacrifice," voluntary militant \\ group (Arabic, Farsi, pl.)
}


fei

ghairat

ghair abl-i qitāl

Ghilzai

badith

haiat

baraba

barakat

hijrah

buddud

ijma

ijtihad

ikbtilaf

jabadah

Jihad

Jihad al-akbar

Jibad al asghar

Jibad bil saif

jinayat

jirga

khan

khums
khuruj
kufr
layeha
madrassa
maharaba
mabaz
mal
mujabid
mujabideen

public property under Islamic law (Arabic)

bravery (Pashto, Dari)

non-combatant (Arabic)

second largest Pashtun tribal confederation in eastern

Afghanistan

recorded sayings, rulings, and teachings of the Prophet

(Arabic)

commissioner, envoy (Pashto, Dari)

highway robbery (Arabic)

movement (Arabic)

migration, alluding to the Prophet's flight from Makka

to Medina (Arabic)

crimes prescribed by the Qur'an and the Hadith the prosecution of which is mandatory (Arabic)

consensus of jurists and scholars of the Muslim world (Arabic)

effort of jurists to arrive at correct judgments in Islamic law (Arabic)

legitimate disagreement (Arabic)

struggle, striving (Arabic)

striving, endeavoring, and struggling by means of speech, action, life, property, and other than these in the path of God (Arabic)

Greater Inner Jihad, spiritual struggle against the inner lower self (Arabic)

Smaller Outer Jihad, physical struggle against the enemy of Islam (Arabic)

Jihad by the sword (Arabic)

offenses of bodily injuries and homicide susceptible of retributive punishment (Arabic, pl.)

assembly (Pashto)

usually a title for a ruler in Turkic and Mongolian languages, but for Persians and Afghans/Pashtuns it is understood as chief and nobleman tax based on one-fifth of the war booty (Arabic) withdrawal from the Muslim community (Arabic) infidel (Arabic)

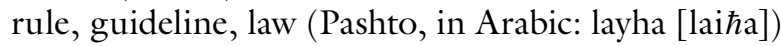
any type of educational institution, whether secular or religious (Arabic)

aggression, offensive violence (Arabic)

front( Pashto,D ari)

wealth or property (Arabic)

a person who engages in Jihad (Arabic, same as mujabed) same as above (Arabic, same as mujabedin, or mujabidin, pl.) 


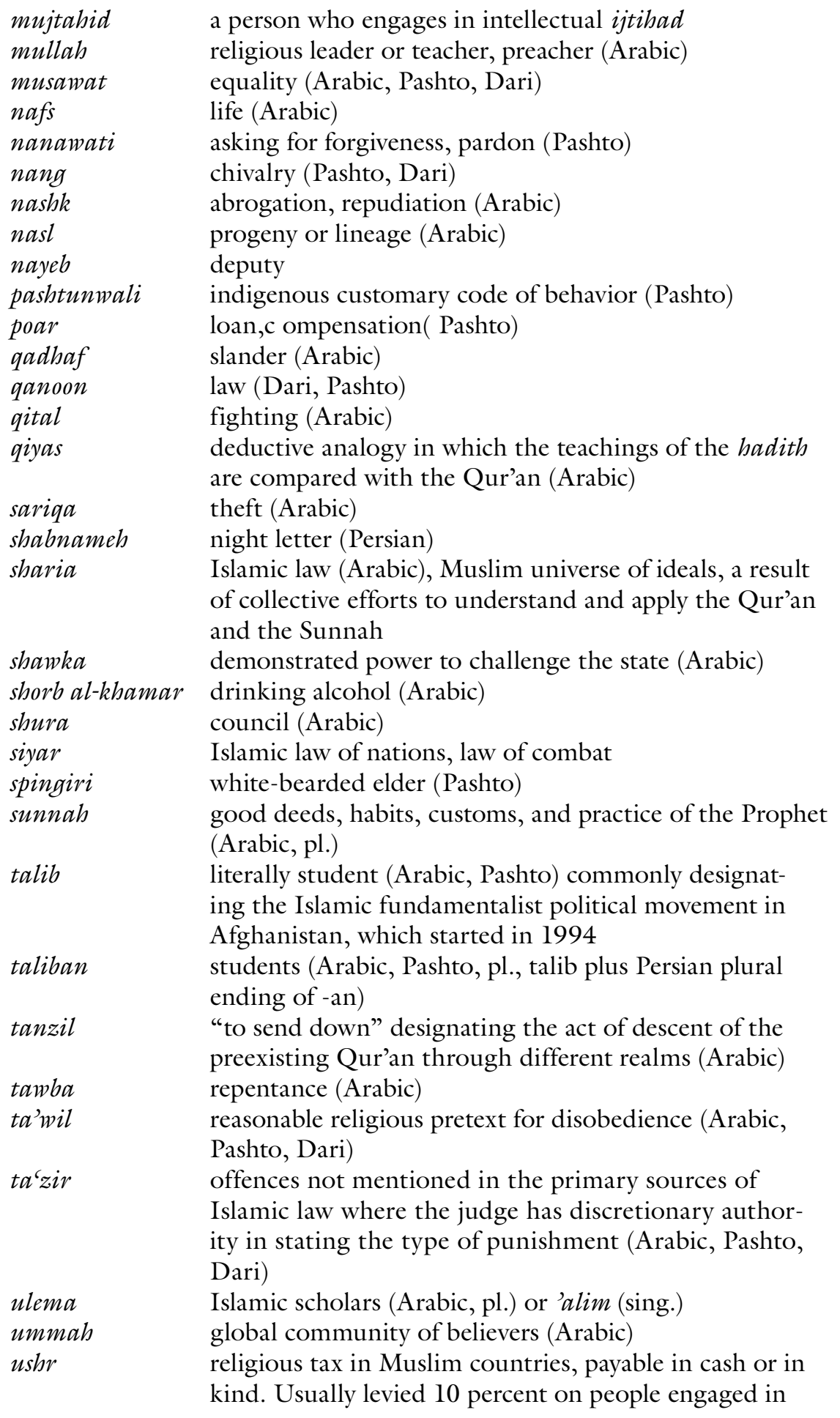


agriculture, livestock-raising, fishing, or crafts (Arabic, Pashto)

usool

$u z r$

zakat

zamin

zan

$z a r$

zina rules (Arabic, Pashto, Dari)

asking for forgiveness among communities (Pashto)

religious tax on assets and liquidity (Arabic)

land (Dari)

women (Dari)

gold (Dari)

adultery/fornication (Arabic) 